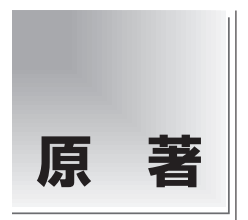

論文受付

2020 年 6 月 3 日

論文受理

2020 年 9 月 25 日

Code No. 251

\section{畳み込みニューラルネットワークによる 画像ノイズ分類を応用した CT 画像の線量評価 : ファントムによる基礎的検討}

\author{
杉野晶一 ${ }^{1}$ 白石順二 ${ }^{2}$ \\ 1 熊本大学大学院保健学教育部 \\ 2 熊本大学大学院生命科学研究部
}

\section{緒 言}

X 線 computed tomography $(\mathrm{CT})$ 装置を用いた撮影 では, 線量管理と画質の最適化が重要視されている. CT の線量指標には volume computed tomography dose index $\left(\mathrm{CTDI}_{\mathrm{vol}}\right)$ が広く用いられているが，特定の 大きさのアクリルファントムを用いた測定值であり, 患者の吸収線量を示す值でないため, 実効線量やがん のリスクの推定に用いるべきでないという意見もあ る ${ }^{1,2)}$ 。一方，より実際の吸収線量に近い值を求めるた
め, 近年, CT 画像の線量評価をモンテカルロシミュ レーションにより推定する手法が提案されている3 ${ }^{3}$.

しかし，モンテカルロシミュレーションには高額な専 用ソフトウェアが必要であるため, あらゆる施設で利 用できるわけではない4).

一般的に, CT 検査における撮影線量の変化は CT 画像のノイズに影響し，線量を少なくすると，画像中 のノイズが多くなる傾向にある。 ノイズが多くなると 病変の信号がノイズに埋もれてしまい，画像診断の弊

\title{
Application of Convolutional Neural Network for Evaluating CT Dose Using Image Noise Classification: A Phantom Study
}

\author{
Masakazu Sugino $^{1}$ and Junji Shiraishi ${ }^{2 *}$ \\ ${ }^{1}$ Graduate School of Health Science, Kumamoto University \\ ${ }^{2}$ Faculty of Life Sciences, Kumamoto University
}

Received June 3, 2020: Revision accepted September 25, 2020

Code No. 251

\section{Summary}

Purpose: It is well known that there is a trade-off relationship between image noise and exposure dose in X-ray computed tomography (CT) examination. Therefore, CT dose level was evaluated by using the CT image noise property. Although noise power spectrum (NPS) is a common measure for evaluating CT image noise property, it is difficult to evaluate noise performance directly on clinical CT images, because NPS requires CT image samples with uniform exposure area for the evaluation. In this study, various noise levels of CT phantom images were classified for estimating dose levels of CT images using convolutional neural network (CNN). Method: CT image samples of water phantom were obtained with a combination of mAs value (50, 100, $200 \mathrm{mAs}$ ) and X-ray tube voltage $(80,100,120 \mathrm{kV})$. The CNN was trained and tested for classifying various noise levels of CT image samples by keeping 1) a constant $\mathrm{kV}$ and 2) a constant mAs. In addition, CT dose levels (CT dose index: CTDI) for all exposure conditions were estimated by using regression approach of the CNN. Result: Classification accuracies for various noise levels were very high (more than 99.9\%). The CNN-estimated dose level of CT images was highly correlated ( $\mathrm{r}=0.998)$ with the actual CTDI. Conclusion: CT image noise level classification using CNN can be useful for the estimation of $\mathrm{CT}$ radiation dose.

Key words: noise power spectrum, volume computed tomography dose index ( $\mathrm{CTDI}_{\mathrm{vol}}$ ), dose evaluation, convolutional neural network 
Table 1 CTDI $_{\text {vol }}$ of each scan condition

\begin{tabular}{ccc}
\hline \hline X-ray tube voltage $(\mathrm{kV})$ & Tube current-time product $(\mathrm{mAs})$ & CTDI $_{\text {vol }}(\mathrm{mGy})$ \\
\hline 80 & 50 & 1.2 \\
& 100 & 2.4 \\
200 & 4.8 \\
& 50 & 2.3 \\
100 & 100 & 4.7 \\
& 200 & 9.4 \\
& 50 & 3.8 \\
120 & 100 & 7.7 \\
& 200 & 15.3 \\
\hline
\end{tabular}

害となるため，日々の点検でノイズを正確に評価する ことが重要である5)。ノイズの評価には C T 值の standard deviation (SD) を測定する方法が簡便であ り，広く利用されている。また，SDを用いるノイズ の評価方法はノイズの周波数特性を考慮していないた め, より詳細なノイズの測定にはノイズの周波数ごと の測定が可能な noise power spectrum(NPS) が用いら れる。しかし，ノイズ特性評価に一般的に用いられる NPS は, 画像上の均一な部分を必要とするため, 複雑 なテクスチャを有する臨床画像に適用することは難しい.

本研究では, 深層学習の一つである睤み込みニュー ラルネットワーク (convolutional neural network: $\mathrm{CNN})$ を用いることにより CT 画像のノイズレベルを 判定し，その結果から CT 画像の線量を推定する手法 の開発を試みる。画像に含まれるノイズ成分と被写体 の情報から線量を推定することが可能になれば，患者 の被ばく管理が容易になり，被ばくの軽減につながる と考えられる。

近年，CNN を用いた同様のアプローチが報告され ており，その報告では，シミュレーションにより作成 したさまざまなノイズ特性の CT 画像の分類につい て, 高い精度 $(92.6 \%)$ が示されている ${ }^{6)}$. 本研究は, CNN によるノイズ評価の手法を更に拡張して, CT 画 像のノイズ特性から線量を評価するシステムの開発を 試みる。本研究では, 基礎的検討として水ファントム から得られた CT 試料画像を用いるが，一般的な臨床 画像を想定して，CT 画像の中心部と辺縁部のノイズ 特性の変化, 臨床画像の限定した領域からデー夕を取 得する場合を考慮して, 線量推定に用いる正方形の関 心領域 (region of interest: ROI)のサイズが分類精度に 与える影響についても検討した。

\section{1. 方 法}

\section{1-1 使用機器および撮影条件}

CT 装置として, 16 列検出器を装備した multi detector CT (MDCT) 装置, Supria Advance（日立製作 所, 東京)を使用した。また,ノイズ特性評価の対象に するファントムは, 直径 $210 \mathrm{~mm}$ の水ファントムを使 用した。水ファントムの撮影条件は, 管電圧を 80 , $100,120 \mathrm{kV}$ ，管電流時間積を 50, 100, $200 \mathrm{mAs}$, ス ライス厚 $5 \mathrm{~mm}$, field of view(FOV) $350 \mathrm{~mm}$ で撮影し た。画像再構成法はフィル夕逆投影法 (filtered back projection: FBP)で行い, 再構成関数は標準再構成関 数 standard を使用した。 3 種類の管電圧および 3 種 類の管電流時間積の 9 通りの組み合わせで, 各撮影条 件で 5 回ずつ撮像し, 45 枚の試料画像を取得した。な お，試料画像取得の際に，それぞれの撮影条件におい てコンソールに表示された CTDI $\mathrm{yol}_{\mathrm{vo}}$ を本研究における $\mathrm{X}$ 線被ばく情報の基準として用いた (Table 1).

第 1 の検討項目であるノイズレベルの判定は, 管電 圧一定で $\mathrm{mAs}$ 值 $(50,100,200 \mathrm{mAs})$ を変化させた 3 種 類の画像, $\mathrm{mAs}$ 值一定で管電圧 $(80,100,120 \mathrm{kV})$ を変 化させた 3 種類の画像について, CNN を用いて分類 を行い，それらの結果を同一条件で得られた画像の NPS とCTDI vol $_{\text {l }}$ より検証した。 なお，NPSの測定に は，仮想スリット法と radial frequency 法が用いられ る。仮想スリット法では，解析領域のサイズ(スリッ 卜長)がNPS の精度に影響を及ぼすため,ここでは二 次元パワースペクトルの原点を中心にして, 周波数ご とに平均して, 全周囲の平均的 NPS 值を求める radial frequency 法を用いて NPS を算出した ${ }^{7)}$.

次の過程では, 未知の CT 画像のノイズレベルか ら，その $\mathrm{CTDI}_{\mathrm{vol}}$ を推測することを目的とした CNN の開発を試みた。ここでは, 試料画像のノイズレベル とその CTDI $I_{\mathrm{vol}}$ との関係を回帰応用の CNN で学習さ 
Table 2 Summary of created CNN architecture

\begin{tabular}{lcc}
\hline \hline \multicolumn{1}{c}{ Layer type } & Output size & Filter size/stride \\
\hline Input image & $30 \times 30 \times 1$ & \\
CONV & $30 \times 30 \times 32$ & $3 \times 3, \mathrm{~K}=32$ \\
ACT & $30 \times 30 \times 32$ & \\
CONV & $30 \times 30 \times 32$ & $3 \times 3, \mathrm{~K}=32$ \\
ACT & $30 \times 30 \times 32$ & \\
BN & $30 \times 30 \times 32$ & \\
POOL & $15 \times 15 \times 32$ & $2 \times 2$ \\
CONV & $15 \times 15 \times 64$ & $3 \times 3, \mathrm{~K}=64$ \\
ACT & $15 \times 15 \times 64$ & \\
CONV & $15 \times 15 \times 64$ & $3 \times 3, \mathrm{~K}=64$ \\
ACT & $15 \times 15 \times 64$ & \\
BN & $15 \times 15 \times 64$ & \\
POOL & $7 \times 7 \times 64$ & $2 \times 2$ \\
FC & 512 & \\
ACT & 512 & \\
DROPOUT & 512 & \\
FC & 3 & \\
SOFTMAX & 3 & \\
\hline
\end{tabular}

せ，その推定精度をラウンドロビン法による学習とテ ストにより検証した。

\section{1-2 CNN の構造}

本研究では, deep learning 開発環境として MATLAB R2019b (Mathworks, Natick, MA, USA)を使用し た。構築した CNN は，畳み込み層四つ、プーリング 層二つ, 全結合層二つが並ぶ構造で, $\operatorname{miniVGG}^{8)}$ の考
え方を応用した。構築した CNN は，3×3 のフィルタ を 32 個および 64 個もつ罟み込及層 $(\mathrm{CONV})$ をそれぞ れ 2 回学習させ, プーリング層 $(\mathrm{POOL})$ にはプールサ イズを $2 \times 2$ ， ストライドを $2 \times 2$ の最大值プーリングを 使用し, 活性化関数 (ACT) として正規化線形ユニッ 卜層 $(R e L U)$ と，畳み込み層の間にバッチ正規化層 (BN) を用いた。構築した CNN で入力画像を $30 \times 30$ とした場合の概要を Table 2 に示す。本研究で用いた $\mathrm{CNN}$ の学習パラメータはエポック数を 50 回, 学習率 を 0.001 , 最適化関数はモーメンタム項付き確率的勾 配降下法 (stochastic gradient descent method: SGDM) とした。なおこれらのパラメータの設定は経験的に 決定した。

$\mathrm{CNN}$ による分類精度の評価は, 交差検証法の一つ である 5 分割交差検証法を用いて，画像ごとに分類精 度を算出し，評価した。この検証法では，5枚の水 ファントム画像のうち 4 枚を学習に用いて, 残りの 1 枚でテストを行うという処理を 5 回繰り返すことで, 5 枚の試料画像すべてを独立してテストすることが可 能になる。

\section{1-3 入力画像の作成}

CNN によるノイズレベルの判定の学習およびテス 卜のための入力画像は, 水ファントム画像内の水相当 部分全体に設定した ROI の画像 (以下, ROI 像) とし た。最初の評価では，ROI 像のサイズが分類精度に与 える影響を検討するため, 水ファントム画像 5 枚に対 して, Fig. 1 に示すように，3 種類のサイズの正方形 の $\mathrm{ROI}(10 \times 10,20 \times 20,30 \times 30$ pixels $)$ で ROI 像を生成し

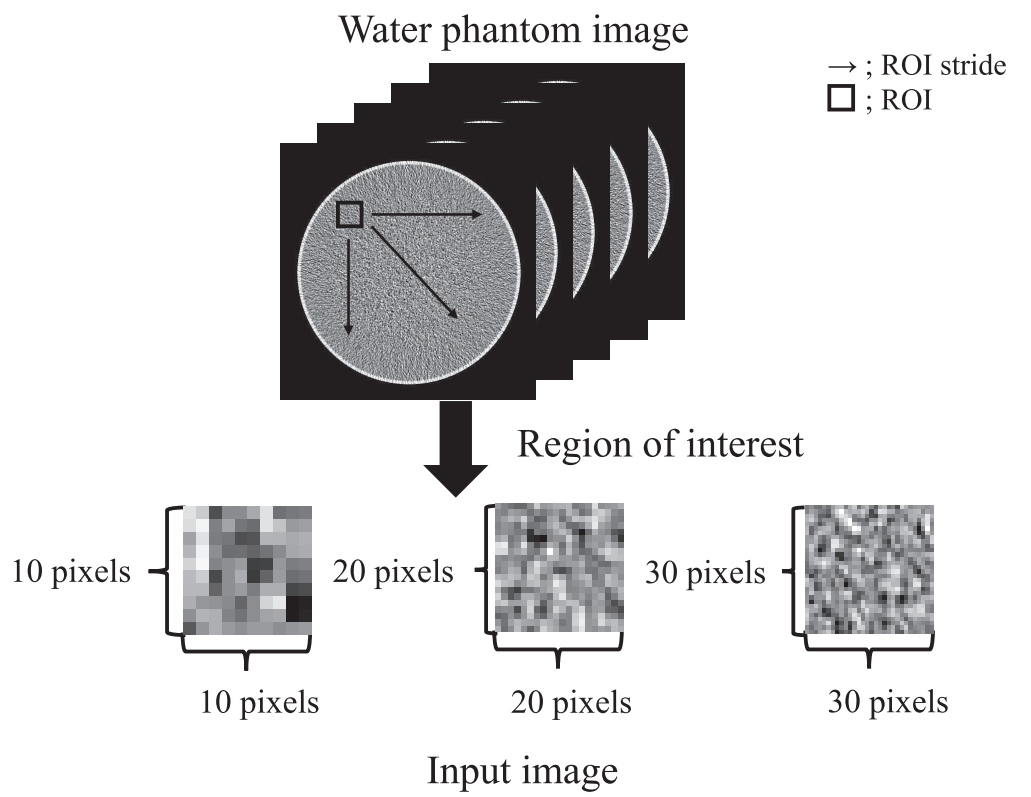

Fig. 1 Illustration of procedure for obtaining input image using water phantom images. 


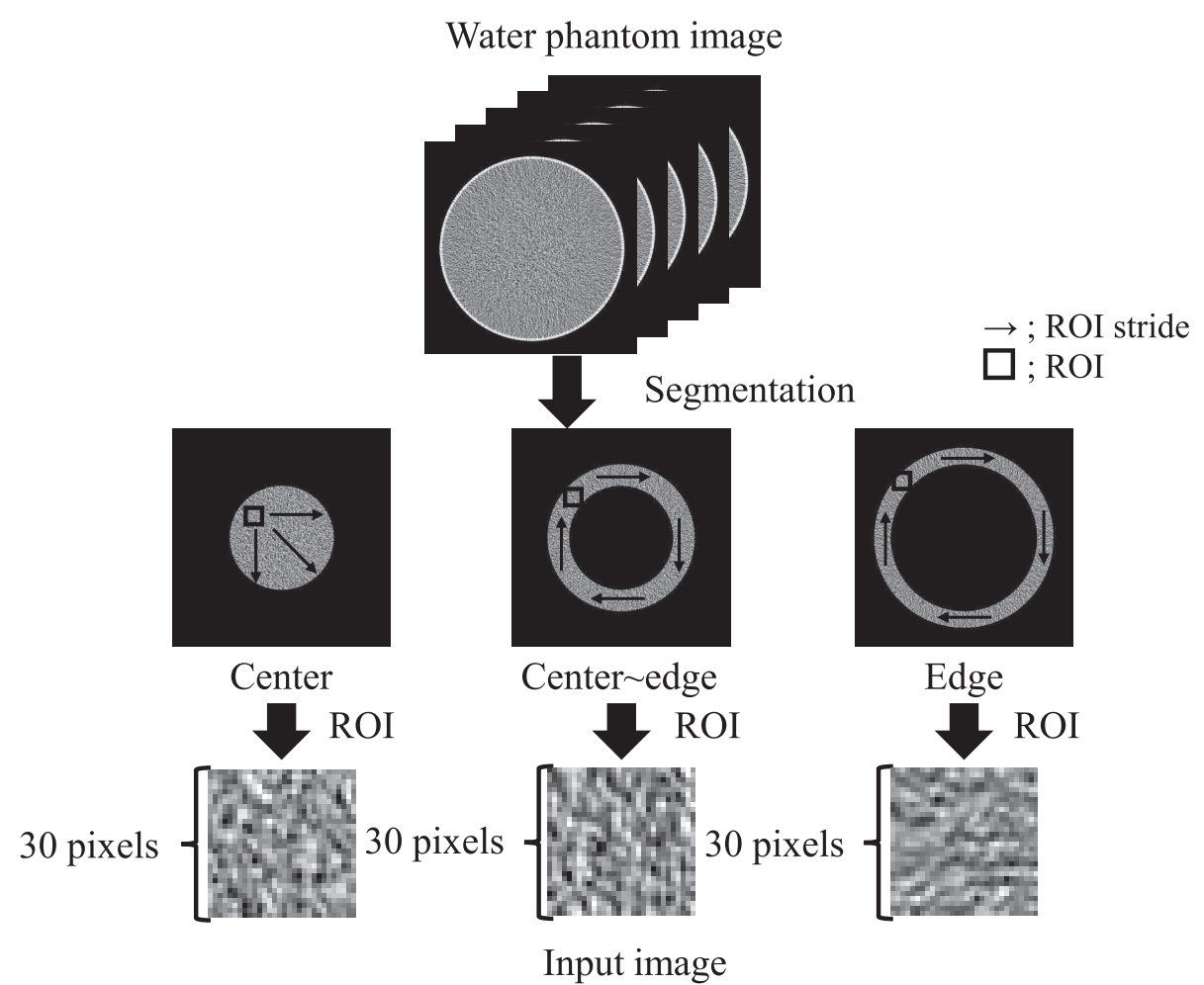

Fig. 2 Illustration of procedure for obtaining input image considering position dependence.

た。なお，学習効果の影響を排除するため, 1 試料画 像当たりの ROI 像の枚数は, ROI サイズが変化して も同一となるように，学習用，テスト用ともに 1 試料 画像当たり 1153 枚とした。 その結果, 学習用画像 4 枚の ROI 数は 4612 枚, テスト用画像では 1153 枚と なり，5分割交差検証法(評価対象の ROI 像の総数は 1153×5=5765 枚)を用いて判定精度による評価を行った。

最初の評価でROI サイズを決定した後，CT 画像に 打ける位置依存性を考慮するため, 試料画像を CT 画 像の中心部, 中心から辺縁部, 辺縁部の 3 力所に, そ れぞれの面積が同じになるように分割し，それぞれの 領域から ROI 像を生成した (Fig. 2). 1 試料画像当た りの ROI 像の枚数は，それぞれの領域について 310 枚とし，それぞれの撮影条件ごとに，それぞれの領域 から学習用に 1240 枚 $(310 \times 4$ 枚), テス卜用に 310 枚 を用いた，撮影条件ごとの判定精度は，領域別に 5 分 割交差検証法(評価対象の ROI 像の総数は $310 \times 5=$ 1550 枚)を用いて求めた。 その後, 試料画像ごとの最 終的な判定精度の評価を，三つの領域について得られ た判定結果の総計 $(1550 \times 3=4650$ 枚)により行った。

最後の評価では，今回設定した 9 種類の撮影条件

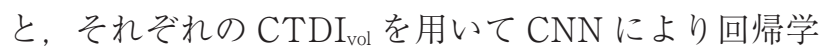
習を行い，未知の試料画像の CTDI $\mathrm{vol}_{\mathrm{vol}}$ を推定する手法 の推定精度の評価を行った。評価は，9種類の撮影条
件における 5 枚の試料画像のうちの 1 枚を試料画像か ら排除した残りの試料画像で CNN を学習させ，排除 した 1 枚の試料画像の CTDI vol $_{\text {r }}$ 推定し, それを全試 料画像について繰り返すラウンドロビン法により, 全 体の推定精度を算出した。 なお，この評価に使用する ROI 像は, CT 画像の中心部から生成した ROI 像 (1 試料画像当たりの評価対象の ROI 像の枚数は 310 枚) とし, 1 枚の試料画像全体の CTDI $\mathrm{V}_{\mathrm{vol}}$ は, 各 $\mathrm{ROI}$ 像に ついて算出された推定 $\mathrm{CTDI} \mathrm{I}_{\mathrm{vol}}$ の平均値とした. 更 に, 各撮影条件の 5 枚の試料画像について推定した平 均の CTDI $\mathrm{vol}_{\mathrm{vol}}$ とコンソールに表示された CTDI $\mathrm{vol}_{\text {vol }}$ (表 示值)の間の相関係数を求めて, 本手法の正当性を検 証した。

\section{2. 結 果}

\section{2-1 ROI サイズと判定精度の関係}

ROI 像のサイズを変化させた場合の判別精度の評 価は, ファントム像の水相当部分全体から生成した ROI 像を用いて行った。評価を行った 3 種類の ROI サイズのうち，30×30 pixelsの ROI 像から得られた判 定結果の混同行列を示す (Table 3a, b). 混同行列の縦 列は実際の撮影条件のクラス, 横列は予測された撮影 条件のクラスを示す。分類精度は, 全体のデー夕の中 で，正しく分類できたものがどれだけあるかという指 
Table 3 Confusion matrix using various noise levels of CT image samples by keeping (a) a constant $\mathrm{kV}$ $(80,100,120 \mathrm{kV})$ and (b) a constant $\mathrm{mAs}(50,100,200 \mathrm{mAs})($ ROI size; $30 \times 30$ pixels $)$

(a)

\begin{tabular}{rrrccc}
\hline \hline $80 \mathrm{kV}$ & $50 \mathrm{mAs}$ & $100 \mathrm{mAs}$ & $200 \mathrm{mAs}$ & Accuracy $(\%)$ & Overall accuracy $(\%)$ \\
\hline $50 \mathrm{mAs}$ & 5765 & 0 & 0 & 100 & \\
$100 \mathrm{mAs}$ & 0 & 5747 & 18 & 99.7 & 99.9 \\
$200 \mathrm{mAs}$ & 0 & 0 & 5765 & 100 & \\
\hline \hline $100 \mathrm{kV}$ & $50 \mathrm{mAs}$ & $100 \mathrm{mAs}$ & $200 \mathrm{mAs}$ & Accuracy $(\%)$ & Overall accuracy $(\%)$ \\
\hline $50 \mathrm{mAs}$ & 5677 & 88 & 0 & 98.4 & \\
$100 \mathrm{mAs}$ & 10 & 5625 & 130 & 97.5 & 98.4 \\
$200 \mathrm{mAs}$ & 0 & 46 & 5719 & 99.2 & \\
\hline
\end{tabular}

\begin{tabular}{rrrccc}
\hline \hline $120 \mathrm{kV}$ & $50 \mathrm{mAs}$ & $100 \mathrm{mAs}$ & $200 \mathrm{mAs}$ & Accuracy $(\%)$ & Overall accuracy $(\%)$ \\
\hline $50 \mathrm{mAs}$ & 5564 & 201 & 0 & 96.5 & \\
$100 \mathrm{mAs}$ & 111 & 5427 & 227 & 94.1 & 95.5 \\
$200 \mathrm{mAs}$ & 0 & 243 & 5522 & 95.8 & \\
\hline
\end{tabular}

(b)

\begin{tabular}{rrrrcc}
\hline \hline $50 \mathrm{mAs}$ & $80 \mathrm{kV}$ & $100 \mathrm{kV}$ & $120 \mathrm{kV}$ & Accuracy $(\%)$ & Overall accuracy (\%) \\
\hline $80 \mathrm{kV}$ & 5765 & 0 & 0 & 100 & \\
$100 \mathrm{kV}$ & 0 & 5653 & 112 & 98.0 & 97.7 \\
$120 \mathrm{kV}$ & 0 & 248 & 5517 & 95.7 & \\
\hline \hline $100 \mathrm{mAs}$ & $80 \mathrm{kV}$ & $100 \mathrm{kV}$ & $120 \mathrm{kV}$ & Accuracy $(\%)$ & Overall accuracy $(\%)$ \\
\hline $80 \mathrm{kV}$ & 5756 & 9 & 0 & 99.8 & \\
$100 \mathrm{kV}$ & 0 & 5491 & 274 & 95.2 & 96.7 \\
$120 \mathrm{kV}$ & 0 & 287 & 5478 & 95.0 & \\
\hline \hline & & & & & \\
\hline \hline $200 \mathrm{mAs}$ & $80 \mathrm{kV}$ & $100 \mathrm{kV}$ & $120 \mathrm{kV}$ & Accuracy $(\%)$ & Overall accuracy $(\%)$ \\
\hline $80 \mathrm{kV}$ & 5754 & 11 & 0 & 99.8 & \\
$100 \mathrm{kV}$ & 0 & 5553 & 212 & 96.3 & \\
$120 \mathrm{kV}$ & 0 & 367 & 5398 & 93.6 & \\
\hline
\end{tabular}

標で，100\%に近づくほど性能が高い。管電圧を 80 , 100，120 kV と一定にして，管電流時間積を 50，100， $200 \mathrm{mAs}$ と変化させた場合 (Table 3a)の全体精度は それぞれ 99.9，98.4，95.5\%となった。また，管電流時 間積を 50, 100, $200 \mathrm{mAs}$ と一定にして，管電圧を 80, $100,120 \mathrm{kV}$ と変化させた場合 (Table 3b)の全体精度 はそれぞれ 97.7，96.7，96.5\%となった。

次に，管電圧を $80 \mathrm{kV}$ を一定にして，管電流時間積 を 50，100，200 mAs と変化させたときの ROI サイズ ごとの分類精度の結果を Fig. 3 に示す。図に示すよ うに，いずれの線量レベルにおいても， ROI サイズが 大きいほど，分類精度が高くなり，ROI サイズが 10× 10 pixels の場合の全体精度は 94.5\%, 20×20 pixels で は 99.3\%, 30×30 pixels では 99.9\%となった。 この傾
向は他の管電圧を一定とした場合も同様であり，すべ ての撮影条件において，ROI サイズが 30×30 pixelsの 場合に，最も高い分類精度を示した (Table 4).

\section{2-2 位置依存性を考慮した場合の判定精度}

位置依存性を考慮し，三つに分割した領域ごとに学 習およびテストを行った場合の判定精度について示す (Table 5a, b). なお，ここからは，2-1の結果から， ROI サイズを 30×30 pixels とした場合の結果のみを 示す。ファントム内の位置依存性を考慮することによ り，考慮しない場合に比べて全体的に分類精度が向上 し，ほとんどの撮影条件において $99.9 \%$ 以上の分類精 度を示した。 


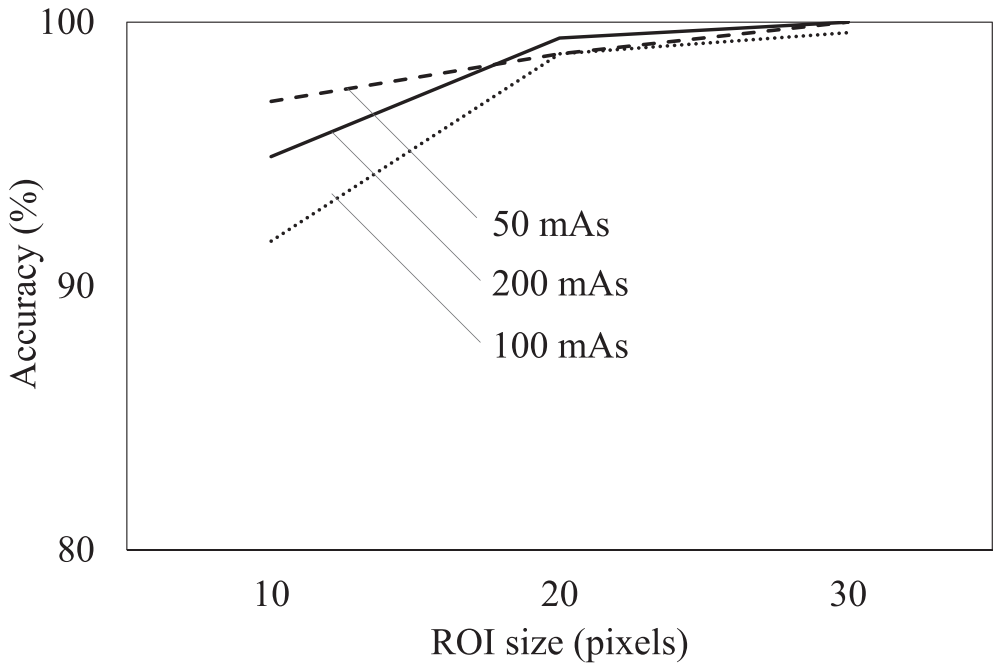

Fig. 3 Change in total accuracy of ROI size $(10 \times 10,20 \times 20,30 \times 30$ pixels $)$.

Table 4 Change in total accuracy of ROI size $(10 \times 10,20 \times 20,30 \times 30$ pixels $)$ by keeping a constant $\mathrm{kV}$

\begin{tabular}{rrrll}
\hline \hline & ROI size & $10 \times 10$ & $20 \times 20$ & $30 \times 30$ \\
\hline $100 \mathrm{kV}$ & $50 \mathrm{mAs}$ & $89.7 \%$ & $97.2 \%$ & $98.4 \%$ \\
& $100 \mathrm{mAs}$ & $78.0 \%$ & $92.1 \%$ & $97.5 \%$ \\
$120 \mathrm{kV}$ & $200 \mathrm{mAs}$ & $88.9 \%$ & $99.1 \%$ & $99.2 \%$ \\
& $50 \mathrm{mAs}$ & $81.2 \%$ & $93.1 \%$ & $96.5 \%$ \\
& $100 \mathrm{mAs}$ & $68.9 \%$ & $90.0 \%$ & $94.1 \%$ \\
& $200 \mathrm{mAs}$ & $84.8 \%$ & $88.5 \%$ & $95.8 \%$ \\
\hline
\end{tabular}

Table 5 Overall accuracy of CNN using various noise levels of CT image samples by keeping (a) a constant $\mathrm{kV}(80,100,120 \mathrm{kV})$ and (b) a constant $\mathrm{mAs}(50,100,200$ $\mathrm{mAs}$ ) considering location dependence

(a)

\begin{tabular}{lccc}
\hline \hline & $80 \mathrm{kV}$ & $100 \mathrm{kV}$ & $120 \mathrm{kV}$ \\
\hline $50 \mathrm{mAs}$ & $100.0 \%$ & $100.0 \%$ & $100.0 \%$ \\
$100 \mathrm{mAs}$ & $100.0 \%$ & $100.0 \%$ & $100.0 \%$ \\
$200 \mathrm{mAs}$ & $100.0 \%$ & $100.0 \%$ & $100.0 \%$ \\
Overall accuracy & $100.0 \%$ & $100.0 \%$ & $100.0 \%$ \\
\hline
\end{tabular}

(b)

\begin{tabular}{lrrr}
\hline \hline & $50 \mathrm{mAs}$ & $100 \mathrm{mAs}$ & $200 \mathrm{mAs}$ \\
\hline $80 \mathrm{kV}$ & $100.0 \%$ & $100.0 \%$ & $100.0 \%$ \\
$100 \mathrm{kV}$ & $99.9 \%$ & $99.9 \%$ & $99.9 \%$ \\
$120 \mathrm{kV}$ & $99.8 \%$ & $99.7 \%$ & $99.8 \%$ \\
Overall accuracy & $99.9 \%$ & $99.9 \%$ & $99.9 \%$ \\
\hline
\end{tabular}

\section{2-3 推定 CTDI ${ }_{\mathrm{vol}}$ の算出と表示值との相関関係}

ラウンドロビン法により, 九つの撮影条件で撮像さ れた 45 枚の試料画像のうちの 1 枚を未知の試料画像 として推定した CTDI ${ }_{\mathrm{vol}}$ の撮影条件ごとの平均と誤差 の結果を Fig. 4 に示す.グラフの横軸は CT 装置に表
示された $\mathrm{CTDI}_{\mathrm{vol}}$, 縦軸は CNN で推定された CTDI を示す。推定 $\mathrm{CTDI}_{\mathrm{vol}}$ の表示 $\mathrm{CTDI}_{\mathrm{vol}}$ に対する推定誤 差は平均で $6.73 \%$ で, 推定誤差の最大は $1.2 \mathrm{mGy}$ 時の 16.9 \% , 最小は $9.4 \mathrm{mGy}$ 時の $0.91 \%$ であった. 以上か ら推定 $\mathrm{CTDI}_{\mathrm{vol}}$ と表示 $\mathrm{CTDI}_{\mathrm{vol}}$ の間には非常に高い相 


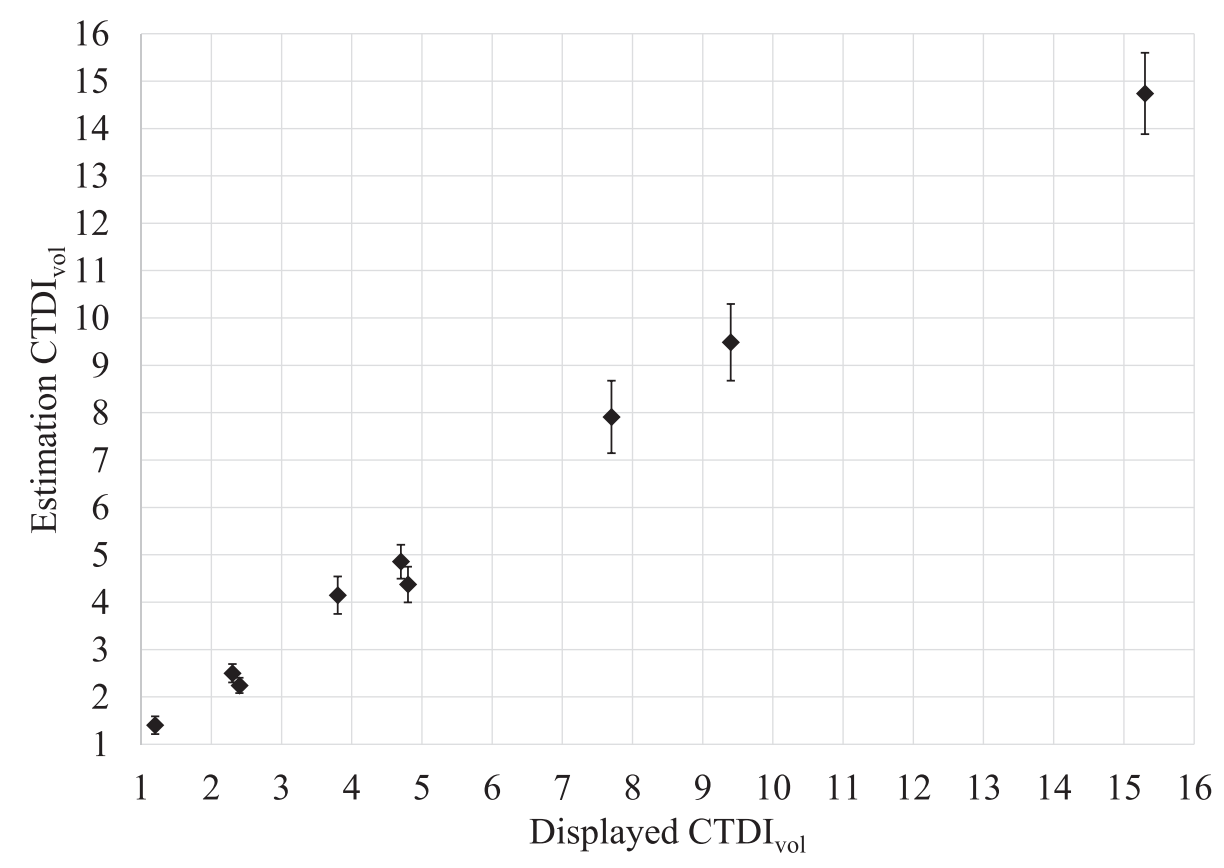

Fig. 4 Comparison of estimation $\mathrm{CTDI}_{\text {vol }}$ using $\mathrm{CNN}$ and exposure dose value displayed on the operator console.

関がある $(r=0.998)$ ことが実証された

\section{3. 考察}

$\mathrm{CNN}$ を用いたノイズレベルの異なる CT 画像の分 類は, $\mathrm{CNN} へ$ の力画像となる $\mathrm{ROI}$ 像の位置依存性 を考慮することで, 非常に高い精度を示した，CT 画 像において, 中心部と辺縁部とではノイズ特性が変化 することは既知の事実であり ${ }^{9)}, \mathrm{CT}$ 画像の中心部から 求められる $\mathrm{CTDI}_{\mathrm{vol}}$ を基準としてノイズレベルの判定 を行うためには，位置依存性を考慮することが必要で あると考えられる。

$\mathrm{CNN}$ への入力画像のサイズについては, 今回の検 討では設定した中で最も大きいサイズの 30×30 pixels とした場合に, 最も高い精度となった。本手法を臨床 画像に応用することを想定した場合，比較的濃度分布 が均一で線量の変化がノイズに反映しているような部 位は，臨床画像の中にそれほど多く存在するとは思わ れないため, ROI 像のサイズはできるだけ小さい方が 望ましいと考えられる。しかし ROI サイズを小さく することにより，データ数の減少に伴うノイズの標準 偏差の変化が，CNNによる判定精度に影響を及ぼす ことが本研究により示唆された。今回は正方形の ROI 像のみについて検討を行ったが, ROI 像の形状に 関しても今後検討の必要がある.

本研究で評価を行った管電圧一定，もしくは管電流 時間積一定の条件の場合, 基準とする $\mathrm{CTDI}_{\mathrm{vol}}$ の值に
は比較的明確な差があり，そのことが本研究における 非常に高い判定精度の理由の一つになっていると考え られる。そこで，CTDI $\mathrm{vol}_{\mathrm{vo}}$ の差が非常に小さい 3 種類 の撮影条件について，追加検討を行った。評価の対象 としたのは，管電圧と管電流時間積の組み合わせと $\mathrm{CTDI}_{\mathrm{vol}}$ が $80 \mathrm{kV}-200 \mathrm{mAs}$ (4.8 mGy)， $100 \mathrm{kV}-100$ mAs (4.7 mGy), $120 \mathrm{kV}-50$ mAs (3.8 mGy)について である。これらの三つの撮影条件の試料画像を Fig. 5 に示す，図から明らかなように，三つの画像のノイズ レベルはほぼ同等であり(水ファントム画像 5 枚の 80 kV-200 mAs, 100 kV-100 mAs, 120 kV-50 mAs のそ れぞれの平均 SD は $22.7 \mathrm{HU}, 22.0 \mathrm{HU}, 22.2 \mathrm{HU}$ ), 目 視で線量の大小を判定することは極めて困難であると 考えられる。

これらの三つの撮影条件について，位置依存性を考 慮したノイズレベルの判定を CNN により学習・テス 卜した結果，それぞれの撮影条件の分類精度は，80 kV-200 mAs で 71.7\% (3304/4605), 100 kV-100 mAs で 83.3\% (3838/4605), $120 \mathrm{kV}-50 \mathrm{mAs}$ で 67.6\% (3117/4605) となり，全体精度は $74.2 \%$ と本実験の場 合と比較して低い精度となった。そこで，これらの三 つの撮影条件の CT 画像について, NPS を測定した結 果を Fig. 6 に示す。それぞれの NPS について，周波 数 1.0 cycles $/ \mathrm{mm}$ までの積分值 $\Sigma$ NPS を算出した結 果, $80 \mathrm{kV}-200 \mathrm{mAs}$ のNPS は $12287.8 \mathrm{~mm}^{2}, 100$ kV-100 mAs では 10277.7 mm², 120 kV-50 mAs では 


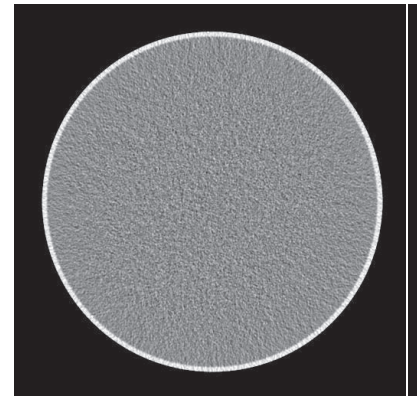

$80 \mathrm{kV}-200 \mathrm{mAs}$

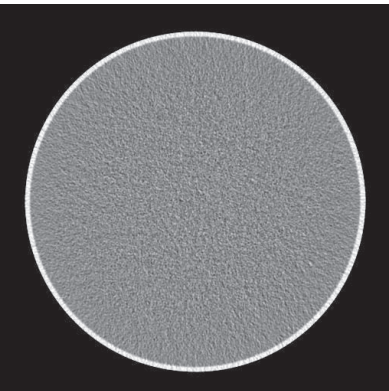

$100 \mathrm{kV}-100 \mathrm{mAs}$

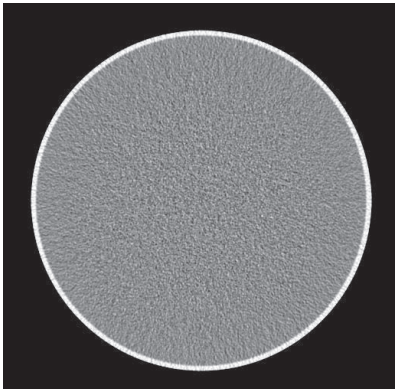

$120 \mathrm{kV}-50 \mathrm{mAs}$

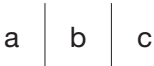

Fig. 5 Similar CTDI water phantom image.

(a) $80 \mathrm{kV}-200 \mathrm{mAs}$, (b) $100 \mathrm{kV}-100 \mathrm{mAs}$, (c) $120 \mathrm{kV}-50 \mathrm{mAs}$

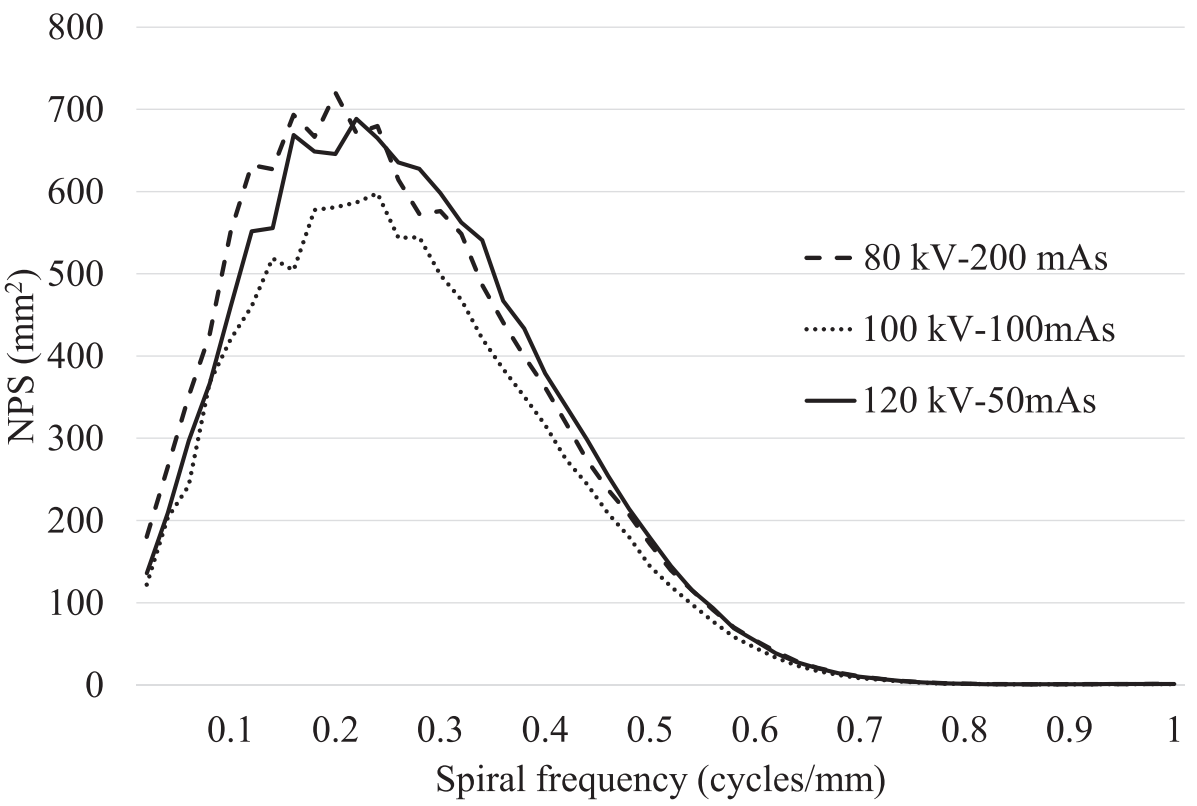

Fig. 6 Each NPS of similar CTDI water phantom image (80 kV-200 mAs, 100 kV-100 mAs, $120 \mathrm{kV}-50 \mathrm{mAs})$.

$12036.8 \mathrm{~mm}^{2}$ となった。三つの撮影条件のノイズレベ ルの差はわずかであるが, $100 \mathrm{kV}-100 \mathrm{mAs}$ の撮影条 件が最もノイズが少なく，線量レベルでは最も低い $120 \mathrm{kV}-50 \mathrm{mAs}$ と最も高い $80 \mathrm{kV}-200 \mathrm{mAs}$ が, とも に似たノイズ特性となることが判明した。この結果 は，CNNによる判定精度と同じ傾向を示しており， CNN による判定結果は，実際のノイズレベルの結果 を反映していると考えられる，以上のことから，CNN を用いたノイズレベルの判定は, NPS による判定と同 等程度に，わずかなノイズ特性の差まで判定すること が可能な手法であると考えられる。

本研究での CNNを用いた推定 $\mathrm{CTDI}_{\mathrm{vol}}$ と表示 $\mathrm{CTDI}_{\mathrm{vol}}$ の相関係数は 0.998 と非常に高い結果を示し ており, CT 画像の画質を基準として線量推定が可能
であることを示した。しかし，表示值 $(4.7 \mathrm{mGy}, 4.8$ mGy) と (2.3 mGy, $2.4 \mathrm{mGy})$ において, 推定 $\mathrm{CTDI}_{\mathrm{vol}}$ で はそれぞれ (4.85 mGy, $4.37 \mathrm{mGy})$ と (2.49 mGy, 2.24 $\mathrm{mGy})$ と線量の大小関係が変化する結果となった。こ の要因を検討するため, 前述の場合と同様に, すべて の撮影条件の試料画像について, 周波数 $1.0 \mathrm{cycles/}$ $\mathrm{mm}$ までの NPS の積分值 $\Sigma$ NPS を算出した結果を Table 6 に示す. Table 6 に示すように，表示值 (4.7 mGy, $4.8 \mathrm{mGy})$ と (2.3 mGy, $2.4 \mathrm{mGy})$ に扔いては, 表 示 $\mathrm{CTDI}_{\mathrm{vol}}$ では増加しているにもかかわらず，逆にノ イズ量が増えていることが判明した。本研究では, $\mathrm{CT}$ 画像から求めた推定 $\mathrm{CTDI}_{\mathrm{vol}}$ と装置の出力に対応 した表示 $\mathrm{CTDI}_{\mathrm{vol}}$ の相関が高いことの検証を目的とし たので，実測した CTDI $I_{\mathrm{vol}}$ ではなく，装置の表示 
Table 6 Comparison of $\mathrm{CTDI}_{\mathrm{vol}}$ and integrated NPS value between 0.0 and $1.0 \mathrm{cycle} / \mathrm{mm}$

\begin{tabular}{cc}
\hline \hline $\mathrm{CTDI}_{\mathrm{vol}}(\mathrm{mGy})$ & Integrated NPS values $(0.0-1.0$ cycles $/ \mathrm{mm})$ \\
\hline 1.2 & 57265 \\
2.3 & 21244 \\
2.4 & 25119 \\
3.8 & 12036 \\
4.7 & 10277 \\
4.8 & 12287 \\
7.7 & 5964 \\
9.4 & 5071 \\
15.3 & 3002 \\
\hline
\end{tabular}

$\mathrm{CTDI}_{\mathrm{vol}}$ を用いた。 今回, 表示 $\mathrm{CTDI}_{\mathrm{vol}}$ の精度検討は 行っていないが, 今後, 臨床応用を目的として研究を 進めるうえでは，実測による正確な $\mathrm{CTDI}_{\mathrm{vol}}$ の取得が 必要であると考える。

本研究の今後の課題として, 画像再構成法がFBP 法に限定されている点が挙げられる。近年, アーチ ファクトやノイズの低減を目的に, 逐次近似画像再構 成法が CT 装置に多く導入されている。一般的に FBP 画像と逐次近似画像とでは同じ線量であっても ノイズの特徴が異なり, 特に逐次近似画像では, 各装 置で採用されている逐次近似の手法が異なるため, 本 提案手法を適用するためには, 装置ごと, また再構成 パラメータごとに試料画像を作成し学習させる必要が ある, そのため, 今後, 逐次近似再構成画像に対して
も検討が必要であると考える.

また，本研究では，規格化されたファントムを使用 したため, 患者サイズ, 吸収体の変化が考慮されてい ない，患者サイズ，吸収体の違いによってX 線吸収 は変化し，ノイズは変化する，吸収体が異なる場合で は線量ごとにノイズの変化が異なるため, ほぼ同様の 傾向が得られると考えられる。今後, 本手法を臨床画 像に応用するためには，患者サイズや吸収体の違いが 本手法に与える影響についても検討する必要がある.

\section{4. 結 語}

9 通りの管電圧と $\mathrm{mAs}$ 值の組み合わせにより撮影 条件を変化させて撮像したノイズレベルが異なるファ ントム像から得られた CT 画像を試料画像とした。 $\mathrm{CNN}$ を用いて CT 画像のノイズレベルの自動判定を 試み, CT 画像内の位置依存性を考慮することで, 判 定精度が非常に高くなることを証明した，更に，線量 レベルが未知の CT 画像の CTDI $\mathrm{vol}_{\mathrm{vol}}$ を推定する手法を 提案し，非常に高い精度で推定が可能であることを実 証した。

本研究の要旨は第 47 回日本放射線技術学会秋季学 術大会 (2019 年, 大阪)にて発表した.

\section{利益相反}

筆頭著者㧍よび共著者全員が開示すべき利益相反は ない.

\section{参考文献}

1) Boone JM, Strauss KJ, Hernandez AM, et al. Size-specific dose estimate (SSDE) for head CT: the report of AAPM Task Group 293. AAPM 2019: 1-24.

2) McCollough $\mathrm{CH}$, Leng $\mathrm{S}, \mathrm{Yu} \mathrm{L}$, et al. CT dose index and patient dose: they are not the same thing. Radiology 2011; 259(2): 311316.

3) Oono T, Araki F, Tsuduki S, et al. Monte Carlo calculation of patient organ doses from computed tomography. Radiol Phys Technol 2014; 7(1): 176-182.

4）入内島明子, 福島康宏, 小倉明夫. 線量一元管理ソフト ウェアを用いた CT 線量指標による臓器線量推定法. 日 放技学誌 2018; 74(1): 22-28.

5) 後藤光範, 佐藤和宏, 水口早苗, 他. CT 画像の雑音測定 における低周波数領域での精度向上. 東北大保健紀 2011; 20(1): 55-61.

6) Hayashi N, Maruyama T, Sato Y, et al. Evaluating medical images using deep convolutional neural networks: A simulated CT phantom image study. Technol Health Care 2020; 28(2): 113-120.

7）市川勝弘, 原 孝則, 丹羽慎次, 他. CT 画像におけるノ イズパワースペクトル算出方法の比較評価. 医用画像情 報会誌 2008; 25(2): 29-34.

8) Ismail A, Ahmad SA, Soh AC, et al. Improving convolutional neural network (CNN) architecture (miniVGGNet) with batch normalization and learning rate decay factor for image classification. International Journal of Integrated Engineering 2019; 11(4): 51-59.

9) Pahn G, Skornitzke S, Schlemmer HP, et al. Toward standardized quantitative image quality (IQ) assessment in computed tomography (CT): A comprehensive framework for automated and comparative IQ analysis based on ICRU Report 87. Phys Med 2016; 32(1): 104-115. 